\title{
ROLE OF MAGNESIUM SULFATE NEBULISATION ON REDUCING THE INCIDENCE OF POST-OPERATIVE SORE THROAT (POST)
}

\author{
Darshna R. Shah', Shruti M. Shah'2, Tapan P. Parikh'3 , Nidhi S. Reshamwala4, Asha J. Chavda ${ }^{5}$
}

${ }_{1}^{1}$ Associate Professor, Department of Anaesthesia, AMC MET Medical College, Ahmedabad, Gujarat, India.

${ }^{2}$ HOD, Department of Anaesthesia, Smt. NHL Municipal Medical College, Ahmedabad, Gujarat, India.

$33^{\text {rd }}$ Year Resident, Department of Anaesthesia, Smt. NHL Municipal Medical College, Ahmedabad, Gujarat, India.

${ }_{4}^{4}$ rd Year Resident, Department of Anaesthesia, Smt. NHL Municipal Medical College, Ahmedabad, Gujarat, India.

53 rd Year Resident, Department of Anaesthesia, Smt. NHL Municipal Medical College, Ahmedabad, Gujarat, India.

\section{ABSTRACT}

\section{BACKGROUND}

Post-Operative Sore Throat (POST) is a common complication of General Anaesthesia. The present study is to investigate the effect of $\mathrm{MgSO} 4$ nebulisation in reducing the incidence of POST.

\section{MATERIALS AND METHODS}

200 patients of ASA grade I and II between 20 and 60 years undergoing elective surgery for less than 2 hours duration under general anaesthesia were selected and distributed into two groups of 100 patients in each group.

Group M: Nebulisation with Inj. Magnesium Sulfate (MgSO4) 3 mL (300 mg). [Inj. MgSO4 (500 mg/mL), $1 \mathrm{~mL}$ of MgSO4 diluted in 5 $\mathrm{mL}$ distilled water and $3 \mathrm{~mL}$ of preparation was given as nebulisation].

Group N: 3 mL of Inj. Normal Saline nebulisation.

Nebulisation was given before induction of General Anaesthesia.

The incidence of POST was noted at $0,2,4,6,8$ and 24 hours post-operatively.

\section{RESULTS}

The incidence of POST was less in Group M than Group N. Maximum significance was seen at $8^{\text {th }}$ hour of post-operative period $(\mathrm{p}<0.05)$.

\section{CONCLUSION}

MgSO4 nebulisation significantly reduces the incidence of POST.

\section{KEY WORDS}

MgSO4 Nebulisation, POST Reduction, NS Nebulisation.

HOW TO CITE THIS ARTICLE: Shah DR, Shah SM, Parikh TP, et al. Role of magnesium sulfate nebulisation on reducing the incidence of post-operative sore throat (POST). J. Evolution Med. Dent. Sci. 2018;7(36):3996-3999, DOI: $10.14260 /$ jemds/2018/892

\section{BACKGROUND}

Post-operative sore throat is a common complication following endotracheal intubation in General Anaesthesia, because of irritation and inflammation of airway. Magnesium has antinociceptive and anti-inflammatory properties by decreasing inflammatory mediators such as histamine, thromboxane and leukotriene, and stabilising T-cells.[1] Tracheal intubation can activate peripherally acting NMDA glutamate receptors. $\mathrm{Mg}^{2+}$ inhibits calcium entry into the cell and blocks NMDA (N-methyl D-aspartate type) receptors.[2,3] Pre-operative magnesium sulfate nebulisation would be effective in treating POST because of its anti-inflammatory and anti-nociceptive effects, ${ }^{[4]}$ so this study was conducted and $\mathrm{MgSO} 4$ nebulisation was given before induction of general anaesthesia and incidence of POST were noted at 0,2 , 4, 6, 8 and 24 hours post-operatively.

'Financial or Other Competing Interest': None.

Submission 24-07-2018, Peer Review 18-08-2018,

Acceptance 24-08-2018, Published 03-09-2018.

Corresponding Author:

Dr. Darshna R. Shah,

Associate Professor,

Department of Anaesthesia, AMC MET Medical College,

Maninagar, Ahmedabad, Gujarat, India.

E-mail: drdrshah69@gmail.com

DOI: $10.14260 /$ jemds $/ 2018 / 892$

\section{MATERIALS AND METHODS}

Approval of study was obtained from the Ethics Committee. Written informed consent was obtained after explanation of study design and goals of study.

A prospective, randomised, double-blind study composed of 100 patients in each group belonging to ASA grade I and II of age 20 - 60 years undergoing elective surgeries. The sample size for the study was taken for convenience. With the help of computer generated random number table and sealed envelope method, the patients were randomly assigned in Control and Test group. The control group consists of 100 patients who received nebulisation of Inj. Normal Saline (Group N) and the Test group consists of 100 patients who received nebulisation with Inj. MgSO4 (Group M). Our hypothesis was to see that MgSO4 nebulisation (Group M) decreases the incidence of POST than the control group. There was no significant difference with regard to age, sex and weight of patients in both groups. The investigator and the patient were unknown of the content used in the nebulisation. All surgeries were done in supine position and duration of anaesthesia was $<2$ hours.

\section{Exclusion Criteria}

- $\quad$ Pre-existing hoarseness or sore throat, upper respiratory tract infection and smoking habit.

- Immunocompromised patients. 
- Patient on immunosuppressant.

- Patient on chronic treatment of CCB (Calcium Channel Blockers) or Magnesium and recent use of NSAIDs.

- Patients having allergy to MgSO4 drugs.

- Patients with Altered Hepatic and Renal Function Test.

- Diabetes Mellitus.

- Patient requiring oral nasogastric tube insertion.

- Mallampati grade more than 2.

- $\quad$ Failed tracheal intubation in first attempt or $>15 \mathrm{~s}$.

All patients were kept Nil by Mouth. IV line was secured and monitors applied.

Nebulisation was given before induction of general anaesthesia.

Individuals were randomly divided into Group $\mathrm{M}$ and Group N.

Group M: Nebulised with $3 \mathrm{~mL}$ (300 mg) Inj. Magnesium Sulfate (MgSO4) [Inj. MgSO 4 (500 mg/mL), $1 \mathrm{~mL} \mathrm{MgSO} 4$ diluted in $5 \mathrm{~mL}$ distilled water and $3 \mathrm{~mL}$ of preparation was given as nebulisation].

Group N: Nebulised with $3 \mathrm{~mL}$ Inj. 0.9\% Normal Saline.

Pre-medication with Inj. Glycopyrrolate $0.2 \mathrm{mg}+$ Inj. Fentanyl $2 \mathrm{mcg} / \mathrm{kg}$ were given 3 mins before induction.

Induction: After pre-oxygenation with $100 \% \mathrm{O}_{2}$ for 3 minutes.

Inj. Thiopentone Sodium 5 - $7 \mathrm{mg} / \mathrm{kg}$.

Inj. Vecuronium $0.08-0.1 \mathrm{mg} / \mathrm{kg}$.

Inj. Lignocaine (preservative free) $1.5 \mathrm{mg} / \mathrm{kg}$.

Intubation done with oral cuffed endotracheal tube number 7.0 in females and 8.0 in males and cuff inflated with minimum air to stop air leak. Cuff pressure kept at 20-22 $\mathrm{cmH}_{2} \mathrm{O}$ with the help of a hand held pressure gauge.

Patient was kept on controlled ventilation on volume A/C mode of ventilator. Anaesthesia was maintained with $50 \% \mathrm{O}_{2}$ plus $50 \% \mathrm{~N}_{2} \mathrm{O}$ plus Sevoflurane $1 \%$ and Inj. Vecuronium 0.01 $0.015 \mathrm{mg} / \mathrm{kg}$ was given intermittently every 20 minutes as maintenance muscle relaxant. The last dose of Vecuronium was given 20 mins prior to extubation.

Intraoperative pulse, blood pressure and $\mathrm{SpO}_{2}$ were continuously measured. Intracuff pressure was adjusted every 30 mins using a hand-held pressure gauge and kept within $20-22 \mathrm{~cm} \mathrm{H2O}$, to limit nitrous oxide related pressure increases.

At the end of surgery, muscle relaxation was reversed with a combination of Neostigmine $0.05 \mathrm{mg} / \mathrm{kg}$ and Glycopyrrolate $0.01 \mathrm{mg} / \mathrm{kg}$. After all the criteria of extubation were met, gentle suctioning was done and cuff was deflated completely and patient was extubated in deep inspiration.

Immediately after extubation and later on i.e. $0 \mathrm{~h}, 2 \mathrm{~h}, 4 \mathrm{~h}$, $6 \mathrm{~h}, 8 \mathrm{~h}$ and $24 \mathrm{~h}$ postoperatively, the incidence and severity of POST was assessed by anaesthetist.

The severity of POST was assessed as four-point scale as graded from $(0$ - 3)

0 -No sore throat.

1- Mild Sore Throat (Complain of soreness only on inquiring).

2-Moderate Sore Throat (Complain of soreness on his/her own).

3-Severe Sore Throat (Change of voice or hoarseness associated with throat pain).
The Sample Size for the study was taken for Convenience Data was collected and comparison was done and evaluated using Chi-square test and significance of $0.05 \quad(95 \%$ confidence interval) $(\mathrm{p}<0.05)$ was considered between the two groups and statistical analysis was done using SPSS software of Windows ver. 20.0.

\section{RESULTS}

200 patients were enrolled in the study and they were randomised into two groups of 100 each, Group M and Group $\mathrm{N}$. There was no significant difference in patients regarding age, weight, time of intubation and duration of anaesthesia.

\begin{tabular}{|c|c|c|}
\hline Groups & MgSO4 (n= 100) & $\begin{array}{c}\text { Normal Saline } \\
(\mathbf{n = 1 0 0})\end{array}$ \\
\hline Age (years) & $34 \pm 10$ & $32 \pm 12$ \\
\hline $\begin{array}{c}\text { Gender } \\
\text { (Male/Female) }\end{array}$ & $60 / 40$ & $70 / 30$ \\
\hline ASA-PS I/II & $67 / 43$ & $77 / 33$ \\
\hline Weight (kg) & $55 \pm 20$ & $60 \pm 15$ \\
\hline $\begin{array}{c}\text { Duration of } \\
\text { Laryngoscopy (sec) }\end{array}$ & $10 \pm 5$ & $12 \pm 3$ \\
\hline $\begin{array}{c}\text { Duration of Surgery } \\
\text { (mins) }\end{array}$ & $60 \pm 30$ & $70 \pm 20$ \\
\hline \multicolumn{2}{|c}{ Table 1 } \\
\hline
\end{tabular}

Incidence of POST was observed at $0,2,4,6,8$ and $24 \mathrm{~h}$ post-operatively. It was seen in $15 \%$ of patients in Group N and $10 \%$ in Group M. Incidence of POST was less in Group M as compared to Group $\mathrm{N}$ at $0,2,4,6,8$ and $24 \mathrm{~h}$. Results were analysed using chi-square test with $95 \%$ confidence interval. Statistical analysis was performed using SPSS version 20.0 for Windows. Maximum decrease in POST was seen in Group M at $8^{\text {th }}$ hour with significance of $<0.05$ as compared to Group N.

\begin{tabular}{|c|c|c|c|}
\hline Time & $\begin{array}{c}\text { Normal Saline } \\
\text { Group (n= 100) }\end{array}$ & $\begin{array}{c}\text { MgSO4 Group } \\
(\mathbf{n = 1 0 0 )}\end{array}$ & P-value \\
\hline $0 \mathrm{~h}$ & 50 & 60 & 0.15 \\
\hline $2 \mathrm{~h}$ & 42 & 58 & 0.023 \\
\hline $4 \mathrm{~h}$ & 47 & 62 & 0.033 \\
\hline $6 \mathrm{~h}$ & 55 & 67 & 0.081 \\
\hline $8 \mathrm{~h}$ & 54 & 79 & 0.0001 \\
\hline $24 \mathrm{~h}$ & 75 & 90 & 0.005 \\
\hline
\end{tabular}

Table 2. Grade 0- No Post-Operative Sore Throat

Grade 0 (No sore throat) was seen in $79 \%$ patients in Group $\mathrm{M}$ and $54 \%$ patients in Group $\mathrm{N}$ with significance of $<0.001 \%(\mathrm{p}<0.05)$ considering statistical significant data.

\begin{tabular}{|c|c|c|c|}
\hline Time & $\begin{array}{c}\text { Normal Saline } \\
\text { Group (n= 100) }\end{array}$ & $\begin{array}{c}\text { MgSO4 Group } \\
(\mathbf{n = 1 0 0 )}\end{array}$ & P-value \\
\hline $0 \mathrm{~h}$ & 27 & 22 & 0.41 \\
\hline $2 \mathrm{~h}$ & 30 & 25 & 0.42 \\
\hline $4 \mathrm{~h}$ & 28 & 22 & 0.32 \\
\hline $6 \mathrm{~h}$ & 25 & 20 & 0.39 \\
\hline $8 \mathrm{~h}$ & 26 & 15 & 0.02 \\
\hline $24 \mathrm{~h}$ & 15 & 6 & 0.03 \\
\hline \multicolumn{3}{|c|}{ Table 3. Grade 1- Mild Sore Throat } \\
(Complain of Soreness only on Inquiring) \\
\hline
\end{tabular}

Mild sore throat of Grade I was noted in both groups, but it was relatively less in Group M. Maximum significance was observed at $8^{\text {th }}$ hour post-operatively $(\mathrm{p}<0.05)$. Mild sore 
throat was observed in 25\% patients in Group N and 18\% in Group M.

\begin{tabular}{|c|c|c|c|}
\hline Time & $\begin{array}{c}\text { Normal Saline } \\
\text { Group (n=100) }\end{array}$ & $\begin{array}{c}\text { MgSO4 Group } \\
(\mathbf{n = 1 0 0 )}\end{array}$ & P-value \\
\hline $0 \mathrm{~h}$ & 15 & 12 & 0.53 \\
\hline $2 \mathrm{~h}$ & 20 & 12 & 0.12 \\
\hline $4 \mathrm{~h}$ & 18 & 13 & 0.32 \\
\hline $6 \mathrm{~h}$ & 15 & 10 & 0.28 \\
\hline $8 \mathrm{~h}$ & 15 & 6 & 0.01 \\
\hline $24 \mathrm{~h}$ & 8 & 4 & 0.23 \\
\hline Table 4. Grade II Moderate Post-Operative Sore Throat \\
(Complain of Sore Throat on His/Her Own)
\end{tabular}

The incidence of grade II POST was $15 \%$ in Group N as compared to $9 \%$ in Group $M$ with maximum significance at $8^{\text {th }}$ hour post-operatively $(\mathrm{p}<0.05)$.

\begin{tabular}{|c|c|c|c|}
\hline Time & $\begin{array}{c}\text { Normal Saline } \\
\text { Group (n= 100) }\end{array}$ & $\begin{array}{c}\text { MgSO4 Group } \\
(\mathbf{n = 1 0 0 )}\end{array}$ & P-value \\
\hline $0 \mathrm{~h}$ & 8 & 6 & 0.57 \\
\hline $2 \mathrm{~h}$ & 8 & 5 & 0.38 \\
\hline $4 \mathrm{~h}$ & 7 & 3 & 0.19 \\
\hline $6 \mathrm{~h}$ & 5 & 3 & 0.47 \\
\hline $8 \mathrm{~h}$ & 5 & 0 & 0.03 \\
\hline $24 \mathrm{~h}$ & 2 & 0 & 0.15 \\
\hline
\end{tabular}

Table 5. Grade III Severe Post-Operative Sore Throat (Change of Voice or Hoarseness associated with Throat Pain)

Incidence of grade III POST was very less in both groups with incidence of 6\% in Group N and 3\% in Group M. Grade III sore throat was not seen in Group $\mathrm{M}$ at $8^{\text {th }}$ hour postoperatively. Significant difference was noted at $8^{\text {th }}$ hour with less incidence of POST in Group M as compared to Group N, $(\mathrm{p}<0.05)$.

A total of 200 patients were taken in study. Incidence of POST was observed at $0,2,4,6,8$ and 24 hours after surgery. The overall incidence of POST was less in Group M than Group N.

\section{DISCUSSION}

Post-Operative Sore Throat is one of the most common complication of General Anaesthesia with incidence ranging from $6.6-90 \%{ }^{[5]}$ For better patient care, it was necessary to reduce such complication and reducing hospital stay of patient. In our study, incidence of POST was observed to be upto $15 \%$ in Group N and 10\% in Group M patients. Incidence and grade of POST was seen at 0, 2, 4, 6, 8 and $24 \mathrm{~h}$. Grade 0 POST was seen in 50\% patients of Group N and 79\% patients of Group M. Grade I POST was seen in 25\% patients of Group $\mathrm{N}$ and $18 \%$ of Group M. Grade II POST was seen in $15 \%$ of Group N and 9\% patients of Group M. Grade III POST was very less in both groups. It was $6 \%$ in Group $\mathrm{N}$ and $3 \%$ in Group M. It was not seen at $8^{\text {th }}$ hour post-operatively in Group M. Significance was seen in reducing POST in Group M as compared to Group N. Maximum significance was seen at $8^{\text {th }}$ hour post-operatively at $0,2,4,6,8$ and $24 \mathrm{~h}$ with $(\mathrm{p}<0.05)$.

To reduce POST, we should use smaller size ET tubes, keeping tracheal cuff pressure not more than that is required to prevent air leak. Also, there should be minimum laryngoscopy time $(<15 \mathrm{~s})$ and gentle oropharyngeal suctioning. ${ }^{[6,7]}$

Other pharmacological agents used earlier include aspirin gargles, benzydamine hydrochloride (BH) gargles, transdermal ketoprofen, lignocaine $10 \%$ spray, IV dexamethasone, beclomethasone gel on tracheal tube and magnesium lozenges. All have been shown to reduce the incidence and severity of POST upto $24 \mathrm{~h}$ postoperatively.[8][7]

Kori et al[9] and Maruyama et al[10] found higher incidence of POST in use of lignocaine jelly as lubricant jelly, so it was not used.

Borazan et al[8] found Magnesium lozenges 30 mins preop effective in reducing both incidence and severity of POST in immediate post-operative period.

Gupta et al[11] assessed the efficacy of MgSO4 nebulisation in reducing POST on rest and on swallowing at all time points $(\mathrm{p}<0.05)$

MgSO4 nebulisation lead to decreased pain and POST after $8^{\text {th }}$ hour post-operatively of surgery as compared to Normal Saline $(\mathrm{p}<0.05)$.

Magnesium toxicity was assessed clinically by watching for depressed reflexes, respiratory paralysis and diaphoresis post extubation in recovery room, but no adverse effect was observed in any patient.

Sore throat was related to endotracheal intubation and cuff pressure leading to localised trauma and leading to aseptic inflammation of pharyngeal mucosa. Magnesium being NMDA receptor antagonist has a role in preventing inflammation and thereby POST.

In Ahuja et al[12] study, a similar mechanism of ketamine is seen to reduce POST as it is an NMDA receptor antagonist.

\author{
Abbreviations \\ POST- Post-Operative Sore Throat. \\ MgSO4- Magnesium Sulphate. \\ NS- Normal Saline. \\ ASA grade- American Society of Anesthesiologists. \\ NMDA- N-methyl-D-aspartate. \\ NSAIDs- Non-Steroidal Anti-Inflammatory Drugs. \\ 02- Oxygen. \\ N20- Nitrous Oxide. \\ IV- Intravenous.
}

\section{CONCLUSION}

The incidence of POST was significantly less in patients from Group M as compared to patients from Group N. The peak effect of $\mathrm{MgSO} 4$ nebulisation was observed at $8^{\text {th }}$ hour postoperatively.

\section{REFERENCES}

[1] Tiffany BR, Berk WA, Todd IK, et al. Magnesium bolus or infusion fails to improve expiratory flow in acute asthma exacerbations. Chest Journal 1993;104(3):831-4.

[2] Lin CY, Tsai PS, Hung YC, et al. L-type calcium channels are involved in mediating the anti-inflammatory effects of magnesium sulphate. $\mathrm{Br} \mathrm{J}$ Anaesth 2010;104(1):44-51. 
[3] Zhu MM, Zhou QH, Zhu MH, et al. Effects of nebulisationulized ketamine on allergen-induced airway hyperresponsiveness and inflammation in actively sensitized Brown-Norway rats. J Inflamm (Lond) 2007;4:10.

[4] Turpin F, Dallérac G, Mothet JP. Electrophysiological analysis of the modulation of NMDA-receptors function by D-serine and glycine in the central nervous system. Methods Mol Biol 2012;794:299-312.

[5] Sumathi PA, Shenoy T, Ambareesha M, et al. Controlled comparison between betamethasone gel and lidocaine jelly applied over tracheal tube to reduce postoperative sore throat, cough and hoarseness of voice. Br J Anaesth 2008;100(2):215-8.

[6] Ratnaraj J, Todorov A, McHugh T, et al. Effects of decreasing endotracheal tube cuff pressures during neck retraction for anterior cervical spine surgery. J Neurosurg 2002;97(Suppl 2):176-9.

[7] Agarwal A, Nath SS, Goswami D, et al. An evaluation of the efficacy of aspirin and benzydamine hydrochloride gargle for attenuating postoperative sore throat: a prospective, randomized, single-blind study. Anesth Analg 2006;103(4):1001-3.
[8] Borazan H, Kececioglu A, Okesli S, et al. Oral magnesium lozenge reduces postoperative sore throat: a randomized, prospective, placebo-controlled study. Anesthesiology 2012;117(3):512-8.

[9] Kori K, Muratani T, Tatsumi S, et al. Influence of endotracheal tube cuff lubrication on postoperative sore throat and hoarseness. Masui 2009;58(3):342-5.

[10] Maruyama K, Sakai H, Miyazawa $H$, et al. Laryngotracheal application of lidocaine spray increases the incidence of postoperative sore throat after total intravenous anesthesia. J Anesth 2004;18(4):237-40.

[11] Gupta SK, Tharwani S, Singh DK, et al. Nebulized magnesium for prevention of postoperative sore throat. Br J Anaesth 2012;108(1):168-9.

[12] Ahuja V, Mitra S, Sarna R. Nebulized ketamine decreases incidence and severity of post-operative sore throat. Indian J Anaesth 2015;59(1):37-42. 